\title{
Analisis Keserasian Belanja Daerah Kabupaten Garut
}

\author{
${ }^{1}$ Abdal, ${ }^{2}$ Herabudin, ${ }^{3}$ Siti Saodah \\ ${ }^{1}$ Administrasi Publik Fakultas Ilmu Sosial dan Ilmu Politik UIN Sunan Gunung Djati Bandung; \\ abdal@uinsgd.ac.id \\ ${ }^{2}$ Administrasi Publik Fakultas Ilmu Sosial dan Ilmu Politik UIN Sunan Gunung Djati Bandung; \\ Herabudin.herabudin@yahoo.co.id \\ ${ }^{3}$ Administrasi Publik Fakultas Ilmu Sosial dan Ilmu Politik UIN Sunan Gunung Djati Bandung; \\ sitisaodah467@gmail.com
}

\begin{abstract}
The problem in this study relates to the level of compatibility of operating expenditures, capital expenditures as well as direct and indirect expenditure in the Budget Realization Report (LRA) Garut district fiscal year 2013-2017. The aim of this study was to determine the level of compatibility of operating expenditures, capital expenditures, as well as direct and indirect expenditure on Budget Realization Report (BRR) Garut regency Fiscal Year 20132017. The method used in this research is descriptive method with qualitative approach. Data collection techniques in this study is the observation, documentation, interviews and triangulation. Data analysis techniques in this study is an analysis model of Miles and Huberman which consists of three stages: 1) Reduction of data, 2) data, and 3) conclusion / verification. The result is the expenditures to Garut regency 2013-2017 fiscal year quite well.
\end{abstract}

Keywords: Public Administration, Local Finance, Local Shopping, Harmony Of Shopping.

\section{Pendahuluan}

Laporan Realisasi Anggaran adalah sebuah laporan yang menyediakan dan memberikan berbagai macam data dan informasi yang didalamnya terdapat akun-akun terkait realisasi anggaran, belanja, penerimaan pembiayaan dan pengeluaran pembiayaan yang dilakukan oleh pemerintah daerah dengan anggara selama satu periode. Apabila melihat pada PP Nomor 58 Tahun 2005 Tentang Pengelolaan Keuangan Daerah, maka akan menemukan beberapa aspek dalam laporan realisasi anggaran tersebut. Salah satu diantaranya adalah belanja, yang secara definisi ialah seluruh pengeluaran yang dilakukan oleh bendahara umum daerah yang dapat mengurangi Saldo Anggaran Lebih (SAL) selama satu periode tertentu.

Analisis keserasian belanja dapat digunakan untuk mengetahui keseimbangan yang terdapat dalam belanja yang dilakukan oleh pemerintah daerah. Seluruh rasio yang ada dalam keserasian belanja dihitung sehingga dapat mengetahui keseimbangan dalam belanja pemerintah daerah. Sehingga dapat diperoleh hasil yang akan menunjukkan adanya keseimbangan APBD yang telah dikelola, juga dapat menunjukkan adanya kesesuaian dalam pengelolaan dana yang dimiliki. Terdapat tiga rasio yang dapat dipakai untuk menghitung keserasian belanja, diantaranya yaitu perbandingan belanja operasi terhadap total belanja, perbandingan belanja modal terhadap total belanja, dan perbandingan belanja langsung dan tidak langsung.

Menurut Suwanda (2013:45) mengartikan keuangan daerah yang merupakan hak ataupun kewajiban daerah sebagai kegiatan penyelengaraan pemerintahan di tingkat regional, yang dapat dihitung dengan uang termasuk didalamnya terdapat berbagai bentuk kekayaan 
yang berbuhungan dengan hak dan kewajiban tersebut. Sedangkan menurut Siregar (2015: 12) keuangan daerah yaitu hak dan kewajiban. Hak yang dimaksud adalah hak bagi daerah untuk dapat memperoleh sumber pendapatan daerahnya melalui pungutan pajak di daerahnya, retribusi daerah, dan pendapatan lainnya dari berbagai sumber berdasarkan peraturan perundang-undangan yang berlaku. kewajiban artinya pemerintah daerah diwajibkan mengeluarkan uangnya sebagai upaya pemenuhan atau pelaksanaan segala urusan yang ada dalam pemerintah di daerah yang bersangkutan.

Terdapat kesamaan dari definisi kedua ahli tersebut, yakni hak serta kewajiban. Yang berarti keuangan daerah merupakan hak beserta kewajiban pemerintah di suatu daerah untuk dapat mengurus dan mengatur keuagan daerahnya sesuai dengan kebutuhan dari daerahnya, sumber tersebut bisa didapat dari berbagai sumber seperti dengan memanfaatkan potensi dari daerahnya masing-masing. Ramli (2015:11) mendefinisikan bahwa belanja daerah mencakup seluruh pengeluaran yang terdapat di rekening daerah yang disetorkan ke kas umum daerah sehingga dapat mengurangi akun ekuitas pada dana yang ada, juga sebagai salah satu keharusan pemerintah di daerah selama kurun waktu satu tahun serta pembayarannya tidak dapat diperoleh kembali oleh daerah. Sedangkan menurut Halim (2014:227) belanja daerah merupakan kewajiban pemerintah di suatu daerah yang diakui sebagai pengurangan nilai kekayaan bersih. Menurut Ramli (2015:11) belanja daerah terdiri dari: 1) belanja langsung, yaitu belanja yang berhubungan secara langsung dalam pelaksanaan sebuah program; 2) belanja tidak langsung, merupakan belanja berupa tugas pokok dan fungsi yang tidak berhubungan dengan pelaksanaan sebuah program.

Menurut Mahmudi (2016:160) keserasiaan belanja mempunyai manfaat yakni dapat mengetahui adanya keseimbangan dalam belanja yang dilakukan oleh pemerintah. Hal itu memiliki keterkaitan dengann fungsi dalam suatu anggaran sebagai alat alokasi dana, alat retribusi dana, dan alat keseimbangan. Agar fungsi anggaran dapa berfungi dengan maksimal, maka pemerintah dapat membuat harmonisasi belanja. Untuk mengetahui adanya keseimbangan dalam belanja, dapat dihitung melalui cara berikut :

1. Analisis Belanja Operasi terhadap Total Belanja

Analisis belanja operasi terhadap total belanja adalah membandingkan jumlah keseluruhan yang ada dalam belanja operasi dengan jumlah keseluruhan yang ada dala, belanja daerah. Analisis tersebut memberikan informasi bagi para pengguna laporan terkait besaran belanja daerah yang ditujukan untuk belanja operasi. Rumus yang digunakan dalam menghitung Rasio bellanja operasional terhadap total belanja daerah adalah :

Rasio Belanja Operasi terhadap Total Belanja $=\frac{\text { Realisasi Belanja Operasi }}{\text { Total Belanja Daerah }}$

\section{Analisis Belanja Modal terhadap Total Belanja}

Analisis belanja modal terhadap total belanja adalah perbedaan antara jumlah keseluruhan yang ada dalam belanja modal dengan jumlah keluruhan yang ada dalam belanja daerah. dari analisis ini, pengguna laporan bisa memperoleh informasi mengenai besaran jumlah belanja daerah yang ditujukan terhadap investasi yang berbentuk belanja berupa modal pada anggaran yang bersangkutan. Rumus yang digunakan untuk menghitung perbandingan belanja modal terhadap total belanja adalah: 
Rasio Belanja Modal terhadap Total Belanja $=$

3. Analisis Belanja Langsung dan Tidak Langsung

\section{$\frac{\text { Realisasi Belanja Modal }}{\text { Total Belanja Daerah }}$}

Analisis jumlah belanja langsung dan tidak langsung memberikan manfaat bagi keberhasilan pengelolaan pemerintah di suatu daerah secara internal, yakni bermanfaat bagi cost \& budgetery control. Belanja langsung sudah seharusnya mempunyai nilai yang lebih besar dari pada belanja tidak langsung. Hal tersebut didasari bahwa belanja langsung memberikan pengaruh terhadap kualitas dari output suatu kegiatan. Rasio belanja langsung dan tidak langsung dapat dirumuskan sebagai berikut :

Rasio Belanja Langsung terhadap Total Belanja $=\frac{\text { Realisasi Belanja Langsung }}{\text { Total Belanja Daerah }}$

Rasio Belanja Tidak Langsung terhadap Total Belanja $=\frac{\text { Total Belanja tidak Langsung }}{\text { Total Belanja Daerah }}$

Tabel 1.1

Anggaran dan Realisasi Belanja Pemerintah Kabupaten Garut Tahun 2013-2017

\begin{tabular}{|l|c|c|l|c|}
\hline Tahun & Anggaran & Realisasi & $\begin{array}{c}\text { Persentase } \\
\text { Realisasi } \\
\text { Anggaran }\end{array}$ & Selisih \\
\hline 2013 & 3.082 .495 .644 .933 & 2.934 .073 .591 .407 & $95,19 \%$ & 148.422 .053 .526 \\
\hline 2014 & 3.237 .124 .283 .157 & 3.044 .084 .138 .136 & $94,04 \%$ & 193.040 .145 .021 \\
\hline 2015 & 3.728 .596 .591 .093 & 3.549 .252 .715 .590 & $95,19 \%$ & 179.343 .875 .503 \\
\hline 2016 & 4.046 .134 .278 .152 & 3.691 .518 .655 .216 & $91,24 \%$ & 354.615 .622 .936 \\
\hline 2017 & 4.651 .090 .960 .780 & 4.369 .933 .640 .924 & $93,96 \%$ & 281.157 .319 .856 \\
\hline
\end{tabular}

Tabel diatas menunjukkan jumlah anggaran yang diterima oleh Pemerintah Kabupaten Garut Tahun Anggaran 2013-2017 cenderung mengalami peningkatan. Tetapi jika dilihat pada tabel realisasi, anggaran pada tahun 2013-2017 justru tidak terealisasikan sepenuhnya. Hal tersebut dibuktikan dengan adanya data yaitu pada tahun 2014, anggaran belanja pemerintah Kabupaten Garut sebesar Rp. 3.237.124.283.157, pada realisasinya hanya 90,04\% artinya ada sekitar Rp. 193.040.145.021 belum terealisasikan dari total anggaran pada tahun 2014. Selanjutnya, pada tahun 2016 total anggaran pemerintah di Kabupaten Garut sebesar Rp. 4.046.134.278.152, pada realisasinya mengalami penurunan yakni 91,24\%, artinya sekitar Rp. 354.615.622.936 anggaran tidak terealisasikan. Begitupun pada tahun 2017, anggaran belanja pemerintah adalah Rp. 4.651.090.960.780, sedangkan realisasinya sebesar 93,24\%. Meskipun pada tahun 2016 menunjukkan adanya peningkatan pada realisasinya, tetapi persentase tetap tidak mencapai angka $95 \%$. 
Tabel 1.2

Realisasi Anggaran Belanja Pemerintah Kabupaten Garut Tahun Anggaran 2013-2017

\begin{tabular}{|c|lc|r|r|c|}
\hline Tahun & Belanja & Anggaran & Realisasi & Persentase \\
\hline \multirow{2}{*}{2013} & 1. & Belanja Operasi & $2,311,690,400,755.00$ & $2,240,039,318,386.00$ & $96,90 \%$ \\
\cline { 2 - 7 } & 2. & Belanja Modal & $767,237,915,223.00$ & $69,368,428,641.00$ & $90,24 \%$ \\
\hline \multirow{2}{*}{2014} & 1. & Belanja Operasi & $2,666,767,549,349.00$ & $2,547,803,710,955.00$ & $95,54 \%$ \\
\cline { 2 - 7 } & 2. & Belanja Modal & $560,846,113,328.00$ & $487,453,748,076.00$ & $86,91 \%$ \\
\hline \multirow{2}{*}{2015} & 1. & Belanja Operasi & $3,067,393,868,932.46$ & $2,968,337,362,275.00$ & $96,77 \%$ \\
\cline { 2 - 7 } & 2. & Belanja Modal & $659,552,695,180.54$ & $578,732,262,315.00$ & $87,88 \%$ \\
\hline \multirow{2}{*}{2016} & 1. & Belanja Operasi & $3,336,012,918,186.34$ & $3,093,029,023,520.00$ & $92,72 \%$ \\
\cline { 2 - 7 } & 2. & Belanja Modal & $706,977,400,259.00$ & $597,238,158,316.00$ & $84,48 \%$ \\
\hline \multirow{2}{*}{2017} & 1. & Belanja Operasi & $3,950,396,052,221.17$ & $3,745,060,004,329.00$ & $94,80 \%$ \\
\cline { 2 - 6 } & 2. & Belanja Modal & $688,280,781,653.00$ & $615,046,392,421.00$ & $89,36 \%$ \\
\hline
\end{tabular}

Sumber: LKPD Kabupaten Garut Tahun 2013-2017 (Data Olahan)

Tabel diatas menunjukkan bahwa realisasi anggaran yang digunakan untuk belanja operasi pada Pemerintah Kabupaten Garut tahun 2013-2017 telah mengalami peningkatan. Tetapi pada realisasi belanja modal masih berada di angka 88\%, kecuali pada tahun 2013 yang mencapai pada angka persentase sebesar 90,24\%. Berdasarkan hasil analisis yang dilakukan peneliti terhadap Laporan Keuangan Pemerintah Daerah di Kabupaten Garut, terdapat masalah khususnya pada belanja pemerintah daerah yaitu rendahnya daya serap anggaran belanja pemerintah daerah (belanja langsung maupun belanja tidak langsung).

Apabila melihat pada Peraturan Menkeu Nomor 258/PMK.02/2015 tentang Tata Cara Pemberian Penghargaan dan Pengenaan Sanksi atas Pelaksanaan Anggaran Belanja Kementerian Negara/Lembaga, maka setiap kementerian atau lembaga diwajibkan untuk berfokus pada pelaksanaan realsasi anggarannya secara sah dan formal. Jika hal tersebut tidak terpenuhi, terdapat sanksi yang akan diberikan dengan berdasarkan peraturan yang telah ditetapkan. Sanksi didapatkan apabila daya serap terhadap jumlah anggaran yang telah diberikan capaiannya dibawah 95\%, sanksi tersebut berupa pemotongan anggaran belanja pada tahun yang mendatang.

\section{Metode Penelitian}

Dalam metode penelitan ini, peneliti menggunakan paradigma kualitatif serta jenis penelitian deskriptif. Sumber data diperoleh dari data primer, yakni berupa observasi dan wawancara tidak terstruktur. Sedangkan data sekunder diperoleh peneliti melalui komentar, buku, arsip, dan hal lain yang terkait dengan laporan keuangan khususnya Laporan Realisasi Anggaran. Dalam rangka mengumpulkan data-data penelitian, peneliti memanfaatkan teknik pengumpulan data berupa wawancara secara mendalam dan terstuktur. Dalam melakukan 
wawancara ini, peneliti menentukan sejumlah informan dengan melakukan teknik sampel Purposive, dimana peneliti memilih berbagai macam informan dengan latar belakang yang jelas dan karena mereka mempunyai karakteristik tertentu yang dapat mendukung berhasilnya penelitian ini. Selain itu penelitian ini menggunakan studi kepustakaan, yaitu dimana data penelitian diperoleh dari studi literatur serta tulisan lain yang memiliki keterkaitan dengan penelitian yang sedang dilakukan. Proses analisis data yang dilakukan yaitu dengan analisis data kualitatif, yaitu bahwa untuk menerjemahkan data maka peneliti mencari dan menyusun secara sistematis data yang diperoleh dari hasil wawancara, sejumlah catatan yang diperoleh dari apa yang ditemukan di lapangan, berbagai macam foto dan video dokumentasi, dan lain sebagainya. Apabila ini dijalankan dengan baik, maka peneliti dapat mudah memahami apa yang akan dilakukan dalam menstrukturisasikan data-data, kemudian menguraikannya pada unit-unit, dari itu dilakukan semacam sintesis, membuat sebuah pola yang tersusun dengan baik sehingga dapat ditarik kesimpulan yang dapat untuk memberikan pemahaman kepada yang lainnya.

\section{Hasil Dan Pembahasan}

Untuk mengetahui adanya keseimbangan antar belanja seperti yang terdapat pada Laporan Realisasi Anggaran Pemerintah Kabupaten Garut, maka peneliti melakukan analisis keserasian belanja. Hal ini berkaitan dengan fungsi sebuah anggaran sebagai alat distributor, alat alokasi, serta alat stabilisator. Alat analisis berupa analisis keserasian belanja tersebut diantaranya adalah :

a. Analisis Belanja terhadap Total Belanja

Berikut merupakan tabel dari hasil analisis keserasian belanja yang dilakukan oleh peneliti terkait data belanja operasional Pemerintah Kabupaten Garut tahun anggaran 20132017:

Tabel 3.1

Hasil Rasio Belanja Operasi terhadap Total Belanja Pemerintah Kabupaten Garut Tahun 2013-2017

\begin{tabular}{|c|c|c|c|}
\hline Tahun & $\begin{array}{c}\text { Realisasi Belanja } \\
\text { Operasi (RP) }\end{array}$ & $\begin{array}{c}\text { Total Belanja } \\
\text { Daerah (RP) }\end{array}$ & $\begin{array}{c}\text { Rasio Belanja } \\
\text { Operasi } \\
\text { Terhadap Total } \\
\text { Belanja (\%) }\end{array}$ \\
\hline 2013 & $2,240,039,318,386.00$ & $3.082 .496 .644 .933,00$ & $72,67 \%$ \\
\hline 2014 & $2,547,803,710,955.00$ & $3.237 .124 .283 .157,00$ & $78,70 \%$ \\
\hline 2015 & $2,968,337,362,275.00$ & $3.728 .596 .591 .093,00$ & $79,61 \%$ \\
\hline 2016 & $3,093,029,023,520.00$ & $4.046 .134 .278 .152,35$ & $76,44 \%$ \\
\hline 2017 & $3,745,060,004,329.00$ & $4.651 .090 .960 .780,17$ & $80,52 \%$ \\
\hline
\end{tabular}

Sumber: Laporan Realisasi Anggaran Pemerintah Kabupaten Garut tahun 2013-2017 (data diolah peneliti, 2018)

Dari tabel tersebut, dapat dilihat bahwa rasio belanja operasi pemerintah Kabupaten Garut masih tergolong Fluktuatif. Pada tahun 2013, presentasi belanja pemerintah Kabupaten Garut sebesar 72,67\% dari total belanja yang dianggarkan. Pada tahun 2014, presentase 
meningkat menjadi $78,70 \%$. Pada tahun 2015, presentase belanja pemerintah meningkat kembali menjadi 79,61\%. Pada tahun 2016, presentase belanja pemerintah menurun menjadi $76,44 \%$ apabila dilihat dari tahun sebelumnya. Di tahun 2017, presentase pencapaiannya meningkat kembali yaitu menjadi 80,52\%.

Berdasarkan pada teori Mahmudi, dapat disimpulkan bahwa rasio belanja operasi pemerintah di Kabupaten Garut Tahun 2013-2017 dapat dikategorikan sebagai kategori baik. Hal tersebut dikarenakan total belanja daerah didominasi oleh belanja operasi. Karena, jika dilihat dari presentase capaiannya berada di atas $60 \%$ setiap tahunnya.

\section{b. Analisis Belanja Modal Terhadap Total Belanja}

Tabel berikut merupakan tabel hasil analisis rasio belanja berupa modal Pemerintah Kabupaten Garut, untuk menginformasikan besaran belanja daerah yang ditujukan untuk investasi yang berbentuk modal :

Tabel 3.2

Hasil Rasio Belanja Modal terhadap Total Belanja Pemerintah Kabupaten Garut Tahun 2013-2017

\begin{tabular}{|c|c|c|c|}
\hline Tahun & $\begin{array}{c}\text { Realisasi Belanja } \\
\text { Modal (RP) }\end{array}$ & $\begin{array}{c}\text { Total Belanja } \\
\text { Daerah (RP) }\end{array}$ & $\begin{array}{c}\text { Rasio Belanja Modal } \\
\text { Terhadap Total } \\
\text { Belanja (\%) }\end{array}$ \\
\hline 2013 & $692,368,428,641.00$ & $3.082 .496 .644 .933,00$ & $22,46 \%$ \\
\hline 2014 & $487,453,748,076.00$ & $3.237 .124 .283 .157,00$ & $15,06 \%$ \\
\hline 2015 & $578,732,262,315.00$ & $3.728 .596 .591 .093,00$ & $15,52 \%$ \\
\hline 2016 & $597,238,158,316.00$ & $4.046 .134 .278 .152,35$ & $14,76 \%$ \\
\hline 2017 & $615,046,392,421.00$ & $4.651 .090 .960 .780,17$ & $13,22 \%$ \\
\hline \multicolumn{3}{|c|}{ Sumber: Laporan Realisasi Anggaran Pemerintah Kabupaten Garut } \\
\hline
\end{tabular}

Berdasarkan tabel tersebut, dapat diketahui bahwa keserasian pada rasio belanja modal pemerintah Kabupaten Garut tergolong Fluktuatif. Pada tahun 2013, presentase rasio belanja modal mencapai 22,46\%. Pada tahun 2014, presentase capaian belanja modal menurun menjadi $15,06 \%$. Pada tahun 2015, presentasi capaian meningkat kembali menjadi 15,52\%. Pada tahun 2016 terdapat penurunan kembali dengan presentasi capaian sebesar $14,76 \%$. Begitupun pada tahun 2017, presentase capaian kembali mengalami penurunan yakni menjadi $13,22 \%$.

Menurut Mahmudi (2016: 162-163), penyebab dari hal itu adalah karena pemerintah di suatu daerah yang berpendapatan rendah memiliki orientasi yaitu rajin melakukan belanja berbentuk modal yang termasuk kedalam investasi yang berbentuk modal jangka panjang. Sedangkan pada pemerintah daerah yang berpendapatan tinggi, mereka serngkali sudah mempunyai aset berupa modal yang sudah mencukupi. 
c. Analisis Belanja Langsung dan Tidak Langsung

Berikut ini merupakan hasil analisis pada belanja langsung dan belanja tidak langsung Pemerintah Kabupaten Garut periode 2013-2017:

Tabel 3.3

Hasil Rasio Belanja Langsung Pemerintah Kabupaten Garut Tahun 2013-2017

\begin{tabular}{|c|c|c|c|}
\hline Tahun & $\begin{array}{c}\text { Total Belanja } \\
\text { Langsung (RP) }\end{array}$ & $\begin{array}{c}\text { Total Belanja } \\
\text { Daerah (RP) }\end{array}$ & $\begin{array}{c}\text { Rasio Belanja } \\
\text { Langsung terhadap } \\
\text { Total Belanja (\%) }\end{array}$ \\
\hline 2013 & $1.293 .768 .075 .246,00$ & $3.082 .496 .644 .933,00$ & $41,97 \%$ \\
\hline 2014 & $2.377 .641 .157 .680,00$ & $3.237 .124 .283 .157,00$ & $40,75 \%$ \\
\hline 2015 & $1.519 .556 .268 .861,00$ & $3.728 .596 .591 .093,00$ & $40,75 \%$ \\
\hline 2016 & $1.538 .059 .844 .108,00$ & $4.046 .134 .278 .152,35$ & $38,01 \%$ \\
\hline 2017 & $1.980 .879 .146 .684,00$ & $4.651 .090 .960 .780,17$ & $42,59 \%$ \\
\hline
\end{tabular}

Sumber: data diolah peneliti, 2018

Tabel 3.4

Hasil Rasio Belanja Tidak Langsung Pemerintah Kabupaten Garut Tahun 2013-2017

\begin{tabular}{|c|c|c|c|}
\hline Tahun & $\begin{array}{c}\text { Total Belanja Tidak } \\
\text { Langsung (RP) }\end{array}$ & $\begin{array}{c}\text { Total Belanja } \\
\text { Daerah (RP) }\end{array}$ & $\begin{array}{c}\text { Rasio Belanja } \\
\text { Tidak Langsung } \\
\text { terhadap Total } \\
\text { Belanja (\%) }\end{array}$ \\
\hline 2013 & $1.640 .305 .516 .161,00$ & $3.082 .496 .644 .933,00$ & $53,21 \%$ \\
\hline 2014 & $1.725 .060 .109 .925,00$ & $3.237 .124 .283 .157,00$ & $53,29 \%$ \\
\hline 2015 & $2.029 .676 .446 .729,00$ & $3.728 .596 .591 .093,00$ & $54,43 \%$ \\
\hline 2016 & $2.153 .458 .811 .108,00$ & $4.046 .134 .278 .152,35$ & $53,22 \%$ \\
\hline 2017 & $2.389 .054 .494 .240,00$ & $4.651 .090 .960 .780,17$ & $51,36 \%$ \\
\hline
\end{tabular}

Sumber: data diolah peneliti, 2018

Berdasarkan tabel tersebut, dapat dilihat bahwa keserasian rasio belanja langsung dan tidak langsung Pemerintah Kabupaten Garut tergolong Fluktuatif. Terlihat pada tahun 2013, anggaran belanja langsung yang terealisasi sekitar 41,97\%. Di tahun 2014, besaran belanja langsung 40,75\%. Di tahun 2015-2016 rasio belanja langsung mengalami stagnan dan penurunan, tahun 2015 berjumlah 40,74\% dan tahun 2016 berjumlah 38,01\%. Tahun 2017, rasio belanja langsung mengalami kenaikan kembali yaitu menjadi 42,59\%. Sedangkan untuk belanja tidak langsung pada tahun 2013 yakni sekitar 53,21\%. Tahun 2014-2015 rasio belanja tidak langsung mengalam kenaikan, pada tahun 2014 sebesar 53,29\%, sedangkan pada tahun 2015 sebesar 54,43\%. Namun pada tahun 2016-2017, rasio belanja tidak langsung mengalami 
penurunan. Tahun 2016 sekitar 53,22\%, sedangkan di tahun 2017 turun kembali menjadi $51,36 \%$.

\section{Simpulan}

Dari hasil analisis diatas, dapat disimpulkan bahwa keserasian belanja Pemerintah Kabupaten Garut dilihat dari rasio belanja operasinal terhadap total belanja pemerintah dinilai Fluktuatif, dengan presentase sekitar $72,67 \%$ sampai $80,52 \%$, sedangkan nilai rata-rata presentase adalah 77,59\%. Terdapat kenaikan pada tahun 2013-2015 yang dikarenakan adanya dana yang ditempatkan sebagai belanja pegawai. Hasil rasio belanja modal terhadap total belanja Pemerintah Kabupaten Garut tahun anggaran 2013-2017 menunjukkan adanya keserasian antara belanja pemerintah daerah, yaitu pada belanja modal yang dilakukan pemerintah. Hal tersebut memiliki nilai rata-rata sebesar 16,20\%. Sedangkan belanja modal dinilai Fluktuatif. Keserasian belanja dilihat dari rasio belanja langsung terhadap total belanja dinilai belum cukup baik. Hal tersebut dapat dibuktikan dengan nilai presentase pencapaiannya rata-rata sekitar $37,11 \%$. Untuk belanja tidak langsung yakni sebesar 53,50\%, yang memiliki nilai presentase lebih tinggi dari belanja langsung. Hal tersebut menggambarkan kurang adanya keserasian antara belanja langsung dan tidak langsung. Sebab belanja langsung memberikan pengaruh yang lebih terhadap kualitas output suatu kegiatan.

\section{Referensi}

Anggara, S. (2015). Metode Penelitian Administrasi. Bandung: CV. Pustaka Setia.

Bastian, I. (2006). Akuntansi Sektor Publik: Suatu Pengantar. Erlangga: Jakarta.

Faud, M.F. (2015). Pengantar Akuntansi Keuangan Daerah. Cet.1. Bogor: Ghalia Indonesia.

Halim, A. (2014). Manajemen Keuangan Sektor Publik Problematika Penerimaan dan Pengeluaran Pemerintah. Jakarta: Salemba Empat.

Idrus, M. (2009). Metode Penelitian Ilmu Sosial. Jakarta: Erlangga.

Ikbar, Y. (2012). Metode Penelitian Sosial Kualitatif. Bandung: PT Refika Aditama.

Kuncoro, M. (2004). Otonomi dan Pembangunan Daerah: Reformasi, Perencanaan, Strategi, dan Peluang. Jakarta: Erlangga.

Mahmudi. (2016). Analisis Laporan Keuangan Pemerintah Daerah. Yogyakarta: UPP STIM YKPN.

Maksudi, B.I. (2017). Dasar-Dasar Administrasi Publik dari Klasik Kontemporer. Depok: RajaGrafindo Persada.

Mardiasmo. (2004). Otonomi dan Manajemen Keuangan Daerah. Penerbit Andi: Yogyakarta.

Meleong, J.L. (2013). Metode Penelitian Kualitatif. Bandung: Remaja Rosdakarya.

Nordiawan, D. (2006). Akuntansi Sektor Publik. Jakarta: Salemba Empat.

Pasolong, H. (2010). Teori Administrasi Publik. Bandung: Alfabeta.

Saragih, J.P. (2003). Desentralisasi Fiskal dan Keuangan Daerah Dalam Otonomi. Jakarta: Ghalia Indah. 
Silalahi, U. (2012). Metode Penelitian Sosial (Untuk Guru-Karyawan dan Peneliti Pemula). Bandung: Alfabeta.

Siregar, B. (2015). Akuntansi Sektor Publik (Akuntansi Keuangan Pemerintah Daerah Berbasis Akrual). Yogyakarta: UPP STIM YKPN.

Sugiyono. (2017). Metode Penelitian Kuantitatif, Kualitatif, dan R\&D. Bandung: Alfabeta.

Suwanda, D. (2013). Strategi Mendapatkan Opini WTP Laporan Keuangan Pemda. Jakarta: PPM. 